\title{
High-Involvement innovation: Views from Frontline Service Workers and Managers
}

\section{Introduction}

The nature of work is changing; organisations are demanding more from their employees. It is no longer acceptable to turn up and do your job when organisations are looking for employees to go 'above and beyond' to get extra from their employees. The effect of finanialization has exacerbated trends toward "frontline workers being required to contribute to low level operational decisions" (Thompson, 2013: 478). Thompson and McHugh (2009) highlight that advocates of this change say that "employees' attitudes have to move from grudging compliance to high commitment" (pp. 216). In various work spheres innovation has become the buzzword of the moment and as such managers are looking for 'innovation' from all areas of the organisation. This pursuit of innovation, and ideas as the nuclei of the innovation process, has primarily been driven by firms in order to remain competitive in capitalist environments. Consequently all levels of employees are being encouraged to generate and submit ideas in order to provide the seeds of innovation for the organisation, in what is branded "high involvement innovation" (Bessant, 2003).

This concept has been developed for organisations where people have been viewed as 'cogs in the machine', it is therefore interesting to see what effects high involvement innovation will have in the call centre context which is referred to as 'an assembly line in the head' (Taylor and Bain, 1999). The difference here is that Bessant has referred to obtaining a 'free brain' with 'every pair of hands' which might not be possible when the work is mainly mental as in the case of the call centre industry. Thus, this research aims to explore the impact high involvement innovation activities have on frontline and managerial employees in call centres.

This research is important as it explores what effect these involvement initiatives have on the employees and managers concerned with them. This is valuable since there is no real consensus across human resource management, labour process and critical management fields resulting in a limited conceptualisation of the relationship between management practices, employee experiences and the outcome. This research makes a contribution through the elaboration of current theory to understand the complexities and subtleties that exist between the high involvement management practices and the experience of workers and their managers.

The research is undertaken using seven comparative case studies looking at innovation activities in a number of different types of call centre. Interviews, observations and call listening were done in many of the cases. From the analysis of the testimonies it would seem that the job design, the mechanisms and practices as well as other people's perceptions of involvement influence the experience of frontline and managerial employees. The findings also appear to highlight that high involvement innovation has the potential to intensify jobs (both frontline and managerial employees) when the quantity of ideas submitted becomes a component of the employee performance appraisal system. 


\section{Background literature \\ High involvement work practices}

It is over thirty years ago that Lawler (1986) coined the term 'high involvement management' to describe practices that included the involvement of employees, since then 'high involvement' practices have developed both conceptually and practically. High involvement work practices (HIWP) have their roots in the high performance work system (HPWS) literature. However, there is a confusion in the literature over the various terms used i.e. participation, involvement, commitment. This is due to this topic being examined from different theoretical lenses such as labour process theory, operations management, human resource management, industrial relations (Wood and de Menezes, 2011). What is agreed is that high involvement practices are a dimension of HPWS and so the conceptual definitions of these terms are difficult to separate. It is not the aim in this paper to open up a debate on the various dimensions and conceptualisations of HPWS but to highlight that there is significant overlap between these concepts which are often used interchangeably in many studies. Boxall and Macky (2009) say that high-involvement work practices terminology is best suited and connected to understanding HPWS conceptually as it focuses on work and involvement and is also a less loaded terminology removing the focus from 'performance' from the term HPWS.

Fairly recent quantitative studies have attempted to understand the relationships between various complex dimensions of HPWS. Examining the UK Workplace Employee Relations survey: Ramsey et al. (2000) analysed the 1998 survey results and Wood and de Menezes (2011) analysed the 2004 results to identify the complex and fuzzy relationship between high involvement management practices and high performing work systems and organisational outcomes. Ramsey et al. (2000) present some interesting findings with their analysis providing little support for the assumed relationships that underpin mainstream theories on HPWS, similarly they have also found little support for the labour process or critical management views of HPWS. This opens up some interesting challenges for studying high involvement management practice as there is no simplistic conceptualisation of the relationship that exists between management practices, employee experiences and the outcome. In the decade between these two studies it would seem there is still a need to understand the complexities and subtleties that exist between the high involvement management practices and the experience of workers and their managers.

Doellgast $(2008,2010)$ in her comparative analysis of German and US call centres work reorganisation, shows that there are significant differences between the companies in the respective countries. She puts these results down to differences in institutional supports for workplace and firm level collective voice, or structures that provide workers as a group with a means of participating in management decisions. Concluding that collective voice is critical for encouraging management to adopt highinvolvement work practices in areas such as call centres where the work is rationalised. Taylor and Bain (2001) also state that trade unions are the only way to get any real democratization of call centres. This is interesting since the role of trade unions or other formal industrial relations institutions, in UK call centres, has been generally neglected in relation to high involvement work practices. The UK call centre industry also has considerable pockets of resistance to unionisation (Bain and Taylor, 2002) which allows management practices to remain unchecked, perhaps leading to further routinisation of jobs and higher levels of control by management. Equally, Budd et al. (2010) emphasise the global reduction in union membership has opened up opportunities for alternative 
involvement practices and new forms of collective voice. Thus, the role of formalised industrial relations institutions in involvement practices is altering, possibly becoming less important.

\section{Employee involvement in innovation activities}

Recently there has been an increased interest in the role employees' play in contributing to innovation activities in organisations. Some of this trend could be down to the open innovation agenda (Chesbrough, 2003) which has drawn interest to ideas coming from various sources not just the traditional actors of the innovation process.

There seems to be two separate fields occurring in this area, one using the term 'high involvement innovation' (HII) and the other using 'employee driven innovation' (EDI). With its roots in the general innovation management field, 'High Involvement Innovation' (HII) (Bessant and Caffyn, 1997; Bessant, 2003) describes the use of the wider workforce in the organisational innovation process, mainly to increase the innovative capacity within an organisation. Thus moving away from exclusive model of innovation where only selected employees are permitted to innovate "to extend participation in the process to a much wider population" (Bessant and Caffyn, 1997: 7) and is "about involving people who have not normally been considered part of the creative resources available to the organisation." (Bessant, 20034).

Conversely, a new approach to employee involvement in innovation activities, emerging from workplace learning theory, has been labelled 'employee driven innovation' (EDI) which Høyrup (2012) define EDI as "the generation and implementation of new ideas, products and processes...originating from inter-action of employees, who are not assigned to the task" (pp. 8). They go onto stress that EDI is a new phenomenon, concept and mode of innovation.

While these two areas of research have stemmed from different fields, there are many conceptual crossovers. The EDI literature drawing upon Bessant's terminologies and definitions of innovation (e.g. Høyrup, 2010 and Waite et al., 2012) and HII draws upon workplace learning theory to describe how employees can be developed to take part in the innovation process (Hallgren, 2009). These concepts are also associated with high involvement theory as both HII and EDI streams of research have a strong focus on the role of job design, organisational structures and management practices that can influence the involvement of employees. What both HII and EDI also have in common is how innovation activities take place, with Tidd and Bessant (2009) outlining that most high-involvement innovation activities occurs within the boundaries of the employees day-to-day role, rather than being seconded into a special innovation role. Høyrup (2010) also draws upon Tidd and Bessant (2009) to highlight that most of this activity takes place in some form of group work, although some activity is carried out on an individual basis (Tidd and Bessant, 2009: 119). This conclusion surrounding HII and EDI has serious implications for this research since call centres are renowned for their limited teamwork and their restricted job design.

\section{Influence of job design}

Wood and Ogbonnaya (2016) reflect back to the original concept of high involvement management and restate that job design was the bedrock of the initial conception, with the focus to reverse narrow job specialisation and Tayloristic divisions of labour. It has long been understood that the enrichment of job design is central to the success of high involvement work practices (Wood et al., 2012). 
In their configurations of involvement and intensification Boxall and Mackay (2009) explicate that, in traditional Tayloristic job designs, when intensification is high and involvement is low then there are fake attempts at involvement. This fake involvement results in management demanding more from employees without giving them any increase in empowerment (Delbridge, 2007). Thus employees' jobs and their experience of work is exactly the same, despite a management rhetoric of high involvement. They further say that the ideal state for High Involvement Work Systems (HIWS) is where intensification is low and involvement is high, thus call centres would not be considered as organisations where high involvement practices would be successful at all.

The Taylorised jobs that are commonly discussed in much of the studies of HIWS have focused on manufacturing, rather than the service environment where the effects of Taylorism are felt in a different way (Boxall, 2003; Harley et al., 2010). Thus, Taylorism is a different construct in call centres than in many other Taylorised work environments (Taylor and Bain, 1999), meaning involvement is substantially controlled by management in call centres. Some definitions of EDI focus on employees working together to develop new ideas without the input of management (Høyrup, 2012), this would be a challenge to call centre employees as they are so tightly controlled by management. In fact the job design in call centres destroys the ability for employees to work in teams. Therefore, activities requiring time off the phones is solely within the control of management, restricting the spontaneous collision of ideas that often result in other environments when employees can work together.

The call centre environment leads to individualist behaviour which results in call centre research focusing on improvements in individuals' daily work and neglect the fact that innovation in call centres could be much more than just improving how you do your job. Often agents are the ones gaining direct insights and feedback from a wide variety of customers. So there is potential for call centre employees to generate ideas that reach far beyond the confines of their own job, impacting not just the operations of the call centre but also to the wider organisation (Hertog, 2000).

Wood and Ogbonnaya (2016) say that job enrichment is central to the involvement of employees in the innovation process, stressing that "employees needed to be aware of the wider context of their jobs, participate in this wider context, and be trained accordingly, especially if they were to contribute to innovation" (pp. 4). Further, from the EDI field, Smith (2017) stresses that work should support work-learning practices to enhance organisational innovation. Accordingly, in call centres where jobs are narrow and there is strict divisions of labour, the job design could be considered a major impediment to high involvement innovation.

This paper will examine the experience of call centre employees who have been involved in innovation activities in an attempt to understand what frontline and managerial employees think of the focus on innovation in their workplaces. Using evidence collected from seven UK call centres this paper presents employees and managers views on the involvement of frontline workers in innovation activities.

\section{Method}

This research follows a case study methodology (Yin, 2003) with semi-structured interviews undertaken with managers, team leaders and agents. In total seven call centres were investigated in 
relation to their innovation activities and the involvement of frontline workers. The potential cases were identified through a number of methods; the industry body for the UK contact centre industry, the Customer Contact Association (CCA), was involved in providing a number of potential cases. The CCA used their members list as well as previous winners of the CCA Innovation and People Award to identify potential case companies for the study. Other industry bodies' innovation award winners were also identified. Of these seven cases two call centres did not allow access to agents, in both cases call volumes and time pressures were cited as reasons for not being able to interview frontline staff (these cases are identified by a * in Table 1 ). The cases were examined in relation to the nature of the service provided, the nature of calls, the involvement/innovation activities and the size of the centres. The composition and characteristics of these eight case studies are shown in Table 1 along with the number of interviewees from each case.

\section{Table 1 here}

\section{Data collection}

In each of the cases, where permissible, the interviews were recorded and transcribed. There was also opportunity for observations and call listening at all but one of the sites (no call listening or observations at ITSup). At three of the sites (ITSup, PSIH, Bank) the agent interviews were undertaken as group interviews in order for the organisations to save time. In two of the cases (Insure and PSO) the agent interviews were undertaken between calls, to reduce agents' time away from the phones. There are issues with using the term 'innovation' as it has many different interpretations which makes it difficult to discuss and gain consensus in the interview setting, therefore the term was not used during the interviews. Consequently, the term 'ideas' was used and the interviewees were asked what happened when employees put their ideas forward and how involved they were in developing and implementing the ideas. The main focus of the interviews surrounded questions such as; can you put your ideas forward, how is this done? What happens to the ideas once you have suggested them? What helps you and what hinders you? How are employees involved in improvements within the call centre? The durations of the interviews ranged from 30 minutes to an hour depending on the interview setting i.e. the interviews with the agents were often shorter in duration due to time pressures from the phone whereas the management interviews were conducted away from the call centre floor and often lasted longer.

\section{Data analysis}

The interviews, where possible, were digitally recorded. The interviews undertaken while call listening were not recorded due to the confidentiality issues with recording potential customer interactions. Handwritten notes from these interviews were taken during the sessions. The recordings and handwritten notes were then used to develop synthesised interview notes, these interview notes were then brought together with any observation notes and any documentary evidence, and compiled into case study narratives. This was a challenging step in the methodology due to the nature of the data. The data was complex, sizable and covered many interrelated areas, thus the case study narratives had to be refined through a series of stages in order to become useful. The case study narratives were imported into NVivo 9 where in line with the Gioia et al. (2013) approach a series of inductive themes emerged. This approach to data analysis allows the 'voices' of the interviewees to be represented "which creates rich opportunities for discovery of new concepts rather than affirmation of existing concepts" (pp. 17). Through first-order analysis, themes were constructed using terms taken directly from the interviewees, thus going back and forward through the case study 
narratives. The second stage in the analysis was to introduce some higher level theoretical constructs to organise the messy first-order themes. This resulted in the categories of 'employee involvement experiences', 'the role of the manager' and 'the outcomes of high-involvement innovation' as overarching themes. The second-order themes were then analysed through cross-case analysis to show any common themes cutting across the cases and examine any differences between the types of call centre and their approaches to involvement of frontline workers in innovation activities. This was done using arrays of tables to show detail from the case narratives in comparison to each other. In order to verify the findings from the cases, the narrative from each of the cases were sent to the respective case company for validation and to identify any potential misinterpretations.

\section{Findings and Discussions - Views from frontline call centre employees and managers}

Looking at the involvement of frontline workers in innovation activities the research has revealed a varied range of views but also some similar emergent themes on the subject. These themes are focused around three key areas; involvement of employees in innovation activities, management's role in high involvement innovation and outcomes of involvement in innovation activities. Table 2 provides an overview of the key findings from the case study analysis.

\section{Table 2 here}

From the comparative analysis there seems to be some commonalities emerging among the cases. The findings indicate that the larger call centres have more formalised involvement systems or mechanisms for involvement, whereas the smaller call centres have informal and more participative approaches to involvement for agents in the innovation process. The cases dealing with customers i.e. the general public, also appeared to have more in the way of formalised activities of business improvement which used frontline workers as team members and used their ideas as inputs. One reason for this could be the stresses put on frontline workers when dealing with the public and these involvement activities were seen as alleviation from the stresses. The other explanation could be that in consumer driven environments then the call centres need to be seen to improve their service since call centres are the front face of many organisations. There also seems to be a relationship between the nature of the service provided and the approach to involvement, in call centres which dealt with longer and more complex calls i.e. ManSup, Charity and Public Sector Outsourced (PSO) the nature of the involvement practices were more informal and ideas were suggested to management via informal mechanisms. In contrast, the call centres dealing with more repetitive and shorter calls seemed to have much more formal and distant mechanisms of involvement. In these cases the use of electronic suggestion schemes were used to collect ideas and formal improvement teams were set up. Thus, there could be links to the nature of the service work undertaken potentially as alleviation from short repetitive tasks.

\section{Employee experiences with innovation activities}

\section{Mechanisms and practices of high involvement innovation - The electronic black hole}

It is unsurprising due to the electronic nature of call centre work that the majority of the centres within this study used electronic tools to collect ideas and promote the successful implementation of the ideas. This also allows the agents to input their suggestions without leaving their desks or taking time off the phones. There was some variance in the way electronic tools were used for involvement of 
agents in innovation activities. In some cases they were used by the management team as a buffer and filter for ideas, as many of the managers interviewed said that they directed their employees to the electronic suggestion scheme when they had approached them with issues or problems. However, what was seen across the cases was that the nature of the electronic suggestion schemes differed in the level of formalisation and purpose. In some cases the scheme was an informal sounding board:

"On the intranet there is a blog...it is a high level suggestion scheme and all employees can air their views on this blog" (ManSup, Manager)

In other cases the schemes were much more formal and required a greater depth of information surrounding the idea, meaning that the employee would have to have some knowledge regarding the financial implications of their idea prior to submitting it. This would assume that employees have the necessary skills and knowledge to undertake such a business case to support their idea:

"There is a suggestion portal in place...it will filter out people who want a moan...the idea goes to a change management board to be assessed...good ideas will go to a feasibility review...more information will be gathered with the person who submitted the idea and then budget and resources will be put through" (ITSup, Manager)

There was also some concern about submitting ideas into the electronic suggestion schemes as some interviewees discussed the lack of control over knowing what happened to their ideas once they had been submitted. Interestingly in the PSIH centre where management said that all ideas are responded to within four weeks their agents said that they had no idea what happened to their ideas once they were submitted. This is also echoed by team leader and agent level employees in other centres:

"There is a lot of opportunities to put ideas forward but there is a lot of duplication and there is no evidence of these ideas being implemented...there are thousands of ideas waiting to get implemented...it's like a black hole" (Bank, Team Leader)

This could mean that these electronic suggestion schemes are used by management as a source of ideas and to get a comprehensive view of employees' thoughts but how this is done by management is not always communicated back to the employees. There were also examples of agents suggesting ideas and the idea being implemented by the management team without any further consultation with the agent. Accordingly the agent is not involved in the whole innovation process and is only used at the front end of the process in these centres. In contrast to the electronic suggestion schemes which are supposed to accommodate agents who are physically tied to their desks by their headsets, some of the case call centres got their agents off the phones to be involved in continuous improvement $(\mathrm{Cl})$ or business process improvement (BPI) projects.

\section{Other's perception of high involvement innovation - Off for a skive}

One of the enduring themes through the interviews with both managers and agents was the notion that being involved with innovation activities, especially the $\mathrm{Cl}$ and $\mathrm{BPI}$ projects, had the potential for agents to see it as a mechanism to actively avoid their day-to-day work. This highlights the low trust environment that often prevail in the call centre environment (Mulholland, 2004; Russell, 2008). For example in ITSup, one agents said that: 
"...most of my managers are supportive of the BPI project but some managers think it is namby-pamby stuff and is a waste of time" (ITSup, Agent)

In many of the cases this type of attitude was witnessed from some managers in the centres as agents being taken off the phones was seen as unproductive and a waste of time. Interestingly, the lack of support for these initiatives was primarily seen in the middle management or team leader level managers. One team leader in Insure exemplified this by saying that the formalised business improvement team (known there as green belts) was not useful:

"The green belt stuff is just a jolly away from the phones...they don't really bring anything back with them from it" (Insure, Team Leader)

Given the vast amount of research on management control in call centre literature (e.g. Bain and Taylor, 2000; Kinnie et al., 2000; Callaghan and Thompson, 2001), this attitude towards time off the phones as work avoidance could be understood from a management perspective, but it is notable that this attitude was also shared by the agents peer group:

"I like getting involved in extra $\mathrm{Cl}$ projects but if you get time away from the phones then everyone thinks you are just skiving" (Bank, Agent)

This highlights that even colleagues think that agents involved with innovation activities have been having a break away from the phones and that it cannot be 'real' work. In some centres this has led to some agents being ostracised by their team members as being too close to the management team. This mistrust of the employees who have worked on an innovation activity could be a reaction by the remaining employees as not been given the same opportunities as others (Bolton and Laaser, 2013). The management control issue is still underlying even within the involvement activities, for example in the Insure centre the management had a tight control on the agents that they wanted to participate in their improvement activities and they actively recruited internal agents based on their behaviours and attitudes rather than ability or skill:

"We only want the right people to work on the green belt projects so we have gone through a sort of job application process for people to be selected to work on them...you know the ones who will just see it as a laugh and a skive off the phones" (Insure, Manager)

This highlights that there are many rational and political motivations regarding participation, demonstrating the power relations in the workplace. Howcroft and Wilson (2003) say that management can create a feeling of participation but ultimately it is them who still hold the power and control. This can lead to participation that is symbolic rather than substantive. In reference to Newman and Nobel (1990) they draw attention to the issue of 'pseudo' involvement, where only the compliant are selected for involvement activities. This seems to be the case in many of the call centres within this study, which means that attitude and behaviours are the key for employees to be selected for involvement. 


\section{Nature of the work - Bored to tears or driven to distraction?}

One of the main areas of academic interest has been concerned with the nature of work and the labour process within call centres (e.g. Bain et al., 2002; Deery et al., 2002; Lloyd and Payne, 2009; Jenkins et al., 2010), while there are many variations of work within the call centre industry it does have some characteristics which make it unique - agents have little or no control or visibility over the flow of work coming into them and they are electronically monitored via the IT system. There is also a high performance target culture within the industry and agents' performance is often based on a diverse set of performance indicators. It is therefore unsurprising that the nature of the job was cited as a reason for agents not being able to be involved in innovation activities. A senior manager in the ManSup case illustrates that the nature of the job makes it difficult for agents to put forward their ideas:

"Agents are not encouraged to come up with new ideas enough...it is not that we don't want them to come forward but the nature of the job makes it challenging for the agent" (ManSup, Manager)

The design of call centre jobs is often designed around short call handling times with a high volume of calls, this coupled with challenging performance and productivity targets means that agents often complain of time pressures. The findings show that agents want to be involved in activities that are out with the scope of their job, as seen from the Insure agent's quote below:

"I would like to be more involved in the $\mathrm{Cl}$ projects but we just don't get the time off the phones as we have to meet our targets... when I was involved in a $\mathrm{Cl}$ project before it made your day a bit more interesting not just the same old boring calls one after another" (Insure, Agent)

The agents' desire for involvement was witnessed across the majority of the cases, often to escape the pressures of the repetitive nature of their work, but time was often used as an excuse for agents not to be involved in these activities.

These findings highlight that HII, as with other high involvement management practices are a fragile coating for the "reality of tightened control and further routinized interaction with little material reward" (Bolton and Houlihan, 2005: 689). It seems that the nature of the job, along with the target driven working environment reduces desire of frontline workers and low level management to be involved with innovation activities. In contrast other case centres discussed the positive impact that being off the phones and actively involved in innovation activities had:

"... a lot of jobs are very monotonous and BPI gives them something new and something different, it allows them to progress...I have known some agents that have been miserable in their jobs but after taking part in BPI projects they are really keen and have changed their morale" (ITSup, Agent)

This highlights the routine nature of the frontline employees' jobs and that they are keen to break from the monotony this supports the mainstream view that HWPS and high involvement practices can increase job satisfaction and general wellbeing at work (Lawler, 1986). However, one of the cases 
within this study (Bank) showed the influence performance measurement of ideas can have on employees' wellbeing.

In the Bank call centre, the only centre in this study with a performance metric focused on idea implementation and $\mathrm{Cl}$ involvement, the agents felt strongly about how performance was measured with regard to ideas. This was compounded since their jobs had not changed but they were still expected to have time to suggest and develop ideas:

" $\mathrm{Cl}$ is $25 \%$ of your scorecard...you get marked down if you don't suggest ideas... we have to keep coming up with ideas and this puts a lot of pressure on us...but we have no time to do $i t^{\prime \prime}$ (Bank, Agent)

High involvement practices are an attempt to reverse the Taylorist process of centralising problem solving and decision making in the hands of management (Edwards and Wright, 2001), however from this research it would seem that the job design still hinders full involvement in innovation activities. Boxall and Macky (2009) say that "The acid test of high involvement is not whether a particular practice...is being implemented but whether employees...experience a positive shift in their responsibilities and decision-making powers relative to their historical norm." (pp. 10). However, in the Bank case there is a shift in responsibilities but no change to the job design to allow these new responsibilities to be fulfilled. Thus the agents have been rendered powerless by the nature of the job.

\section{Role of the manager}

As has been stressed by Russell (2008) the voice of management is often missing from research on HPWS so we have looked at the specific role of the manager within the high involvement innovation activities. Across the cases the role of the manager was often discussed in terms of 'pushing' and 'driving', showing that the responsibility for the implementation of these innovation activities was often down to the team leader or manager:

"It is down to managers to push and monitor the suggestion scheme and give feedback to the employees that have taken part" (ITSup, Manager)

The link between the senior management and lower levels of management was also discussed in some of the cases, highlighting that the need for ideas and improvements stems from senior management. What was surprising was that in the ManSup case one of the managers interviewed stressed that some managers do not have the ability to make the improvements expected of them:

"The innovation strategy is driven by the top management, they want and expect things to improve but not all managers are capable of making the change" (ManSup, Manager)

This shows that it is the middle managers who are being set an innovation agenda, by their senior managers, which they need to drive from the lower level employees. Nevertheless it would appear that these middle managers do not have the skills to implement change and improvements within their teams. This focus on top down innovation was also witnessed from an agent's viewpoint: 
"The Manager is constantly looking for "how can we do this better, and what's the best way to do it?" And I'm sure it's coming from his boss as well. And trying to get better results so he'll then come to us and perhaps look at it as a team, or perhaps he's come up with something elsewhere and come in and said "this is what we're going to give it a try for, for the next three months."'" (Insure, Agent)

The views from the managers shows a focus on cost savings via operational and productivity improvements rather than any 'breakthrough' innovation. This is in line with Bessant's (2003) view on high involvement innovation being focused on continual incremental improvements rather than any radical innovations.

However, in one case centre (PSIH) which is a government operated centre the Operations Manager said that the new Minister taking over thought that "the contact centres are his windows on the world". This shows that the senior management in government consider the knowledge from the government call centre as important as a source of public opinions which could potentially drive future policies.

The high-involvement innovation concept discusses the importance of empowering employees to be involved within the innovation process. It was clear from the discussions with the management level employees in the call centres that ideas were encouraged but within a structure, even in the Charity centre the managers spoke about the control that they have over the process:

"Everyone is quite open with new ideas...it is not a free for all either but we will decide on what ideas will go forward" (Charity, Manager A)

This shows that the frontline employees can generate their ideas but the implementation and follow through of the idea will fall under the responsibility of the management team. Across the call centres studied, there were varying degrees of recognition for employees if their ideas were fully implemented and successful. There were also examples of the management culture within some of the cases as they discussed the way agents can challenge current ways of working:

"Empowerment can be dangerous if there are no boundaries or objectives" (ManSup, Manager)

Fuller and Smith (1991) discuss the coercive nature of management within interactive service environments and stress that "profits invariably suffer when workers are prohibited from exercising some degree of autonomy on the job" (pp. 4). However, this research has shown that management can be weary of giving too much empowerment and autonomy to frontline service workers but think they must give the feeling of it in order to retain a profit. Taylor and Bain (2003) highlight this effect by saying that "Management, at least rhetorically, has an interest in obtaining greater levels of commitment from its workforce, an objective which may allow employees to express opinions. Of course, such encouragement to openness has sharply defined boundaries, and is permitted in so far as it benefits the organisation" (pp. 1495). 
The findings from this research seem to show that managerial motives for including employees in innovation activities are complex, some genuinely appearing to use ideas from employees to drive improvement. However, there appears to be another side to the managerial motives. Firstly, innovation activities that take employees away from the phones are used as alleviation from the monotony of the job and can be used as a reward tool by the management to drive 'good' behaviours in the pool of employees. This was found in two of the cases (Insure and Bank), where management advertised roles on improvement teams but only selected agents with the 'right attitude' i.e. not the ones who thought it would just be a skive. Secondly, idea schemes and employee involvement initiatives which focused on the collection of employees ideas were often used as containment of employee grievances. In this way management used the ideas/suggestion schemes to allow employees to vent issues which allowed management to deal with small issues before they became problematic for the management. Thus, containing employees by making them feel like their ideas were being heard. It could be argued that both of these management motives are basically extensions of the management control strategy.

From the view of the management employees it would seem that high involvement innovation can also intensify their jobs. The findings from this study show that management need to be involved in monitoring, selecting and acting on the ideas put into the suggestion schemes by frontline employees. It was also mentioned in a number of cases that management need to 'push' employees to put their ideas forward and get involved in innovation activities, which can be seen as additional burden on their daily pressures. In the ManSup case it was also emphasised that middle management often do not have the skills or abilities to effectively implement the ideas. Further, in some cases where time away from the phones was seen as a 'jolly' management also have to deal with the discontentment of other employees who are not included. It was also stressed in a number of the cases that the need or want for innovation often comes from top management and this is merely filtered through to the lower levels of management in the call centres, thus becoming a tick-box exercise for the lower level managers.

\section{Outcomes of high-involvement innovation Tea and toilet ideas}

The findings show a distinction between centres who collect every idea and comment from their agents and others who solicit only 'good' ideas. The interviews, primarily from managers, reveal that most of the suggestion schemes are to let employees 'let off steam' and have a 'moan' while other centres use it as a means to get involvement and participation from their employees. Still, often the value of employees' ideas is not taken seriously by management:

"We don't just want tea and toilet moans....that's usually the sort of crap we get at these types of meetings or are put into our suggestion scheme... they moan about the food in the canteen, they are not interested in making the business or their jobs better" (Insure, Manager)

Many of the interviews undertaken with the management level employees touched on the notion of involvement: 
"We encourage people to get involved in new ideas and we get them involved in a number of different projects...they can get rewards but it is more to do with getting them involved than the reward" (PSO, Manager)

In many of the cases in this study, the involvement of employees in innovation activities was used as a means to reduce attrition, turnover and to control behaviours of employees. This would account for the lack of seriousness when dealing with employees' ideas. It could be argued that high involvement innovation activities were less about innovation and more about offsetting labour process effects generated by poor job design (Callaghan and Thompson, 2001).

Only two of the call centres identified the role of the customer (client) in generating ideas. This is surprising when much of call centres work comes from directly dealing with customers issues, it would be easy to imagine that some of this customer intelligence would have been fed back into the wider organisations from the agents themselves. It could be that the ideas being suggested by the agents have been triggered by talking and interacting with the customers but they do not make that connection explicitly in their thinking. In the Charity case they said that most of the ideas put forward from frontline employees came from discussing the clients' needs rather than the employees generating the ideas themselves. For example the manager highlights the types of ideas that have come forward:

"Clients' needs drive ideas... we have a book group and nights out for our clients and that has come directly from our guys speaking on a regular basis to our clients" (Charity, Manager)

Interestingly, this call centre does not have any formal productivity metrics or call listening systems and the focus of the centre is to build relationships with the clients - while this might in contrast to the focus and operation of a traditional call centre (Taylor and Bain, 1999) the Charity do classify themselves as a call centre. The technology and premise of the operation are the same as traditional call centres but the approach to and design of work is completely different in the Charity case.

The only other example of customer voice being included in ideas is from the Bank case study where one of the agents said:

"A customer was complaining about something and he said 'why can't you just do it this way?' and I took that idea to a meeting and we have saved a hell of a lot of money because of a very simple idea that came directly from a customer" (Bank, Agent)

The lack of customer voice in the majority of the cases could be due to call centre agents being a small part of a larger, more complex labour process who can "only help customers with severe constraints" (Belanger and Edwards, 2013: 444) which reduces the scope of their knowledge on customer issues.

In other centres suggestion schemes were used to get agents involved within the call centre, there was some evidence to suggest that many of the centres examined in this study were using this type of tool for employee participation purposes rather than innovation. While it could be argued that innovation did come from these suggestion schemes as ideas were implemented and cost savings, productivity improvements and new ways of dealing with the customer were realised, this was not 
the main intention. Often management discussed the use of these schemes to alleviate boredom or give agents a place to go to air their views and combat issues with attrition and retention rates. With one manager from the PSIH Cl team saying that "suggestion schemes are a good way of gaining staff engagement, as they increase morale".

\section{Intensification}

In the Bank call centre, the management team saw the value in employees' ideas such to the extent that they put idea submission (and implementation) onto all employees annual performance appraisals. This resulted in a backlash, with some of the agents seeing it as out with the scope of their job even when it is part of the formal performance system, with one agent saying:

"Why should I given them (management) my ideas...I'm not paid enough to give them my ideas...I'm paid to come in and do my job, why should I go above and beyond...I'm only a back office person what difference can something I say do...it's not going to make millions for the bank, is it?...But we are continually put under pressure to give more and more" (Bank, Agent)

This agent in the Bank centre echoed the views of many of the agents in this centre as she felt under pressure to 'pull something out of the hat' with regards to how to improve the banks business but she did not feel qualified enough to make suggestions based on her level of experience. Paradoxically, when performance measures are used to 'encourage' innovation, the process of generating and formalising ideas becomes more important and stressful for frontline employees.

From the analysis of the testimonies in this study it would seem that high involvement innovation is in tension with the nature of the job in call centres and actually tends towards intensification especially when the quantity of ideas submitted becomes a component of the employee performance appraisal system. From the Bank centre many of the agents interviewed expressed strain and stress in their jobs caused by the expectation to have their ideas implemented while not being in control of the development and implementation process. In a number of other cases, while not directly targeted on suggestions or ideas, the agents did talk about involvement being part of the behaviours element of their wider performance appraisal system. This intensified their jobs from being customer service agents to becoming process improvement analysts. Many of the employees interviewed in the Bank centre discussed the influence productivity targets had on their ability to be involved within the innovation process, and they complained that while ideas and $\mathrm{Cl}$ was on their scorecard it was always productivity that got the priority. This focus on productivity metrics was also highlighted by other centres in this study as a barrier to being involved in the innovation process.

\section{Conclusions}

This research makes a contribution in three main ways. First, this study examined the nuances of high involvement innovation showing that various constructs, such as centre size, structure of jobs and call characteristics, impact on the level of involvement and nature of innovation activities. The findings show that larger call centres with simple, shorter calls favour a more formalised approach to activities whereas call centres with longer more complex calls adopt an informal approach. This rich nuanced approach to employee involvement in innovation activities is missing from many studies. While the findings here have revealed that HII activities were less about innovation and more about offsetting labour process effects generated by poor job, further research is required which investigates, in more 
detail, the implications of call centre type, nature of service and market position on the job design and work pressures in relation to innovation activities.

Second, the findings presented here suggest management perceptions of innovation activities, as well as the job design, have an interplay which can influence the success of the activities. In many of the cases examined, time away from the phones was seen as a waste of time by management. In contrast these findings also show that for frontline employees time away from the phones had a positive impact on their perceptions of job quality, so there is a tension between management beliefs and the actual experiences of employees. The findings also show for EDI or HII to work then management cannot simply play lip service to the concepts. Management practices which use high involvement activities to alleviate the stresses associated with the Taylorised job design and do not value the ideas put forward by employees narrow the scope of the ideas. Bessant (2003) reflects back to the specialisation of tasks, where disconnection between hand and brain took place. Management were the actors with permission to innovate and improve i.e. the 'thinkers', whereas the workers did what they were told i.e. the 'doers'. Thus, the findings of this research confirm that there are still workers in Taylorised jobs where they are more likely to have their contributions marginalised due to this split in thinking.

Third, Aasen et al. (2012) highlight that employee driven innovation is still in an early phase stressing that more qualitative work is required concerning the organisational conditions promoting employees involvement in the innovation process. They say that this type of research is resource intensive to understand how leaders and employees cooperate for innovation such insight will form the basis for new knowledge about mechanisms decisive for the success of EDI. Thus, the findings of this research has made a significant contribution to the emerging body of research on employee involvement in innovation activities by showing how frontline employees work together with management to submit, develop and implement their ideas.

This research raises important questions, for future research, about various aspects of job design, management practices and the influence of institutional support. This research has shown that the heightened targets used in many of the cases has reduced the ability of employees to be involved in any innovation activities. What is not clear from the findings is if performance measures can be used in a more participative way with employees so that they can have less time pressures allowing them to become more involved in innovation activities. Perhaps a more open and inclusive approach to management practices would allow less focus on the quantitative targets and focus more on the qualitative measures. Thus an interesting direction for future research would be to consider the effects of performance measurement systems in the role they play in facilitating high involvement innovation activities. It is surprising that formalised collective voice practices, such as trade unions or works councils, were not mentioned by any of the interviewees in this research. This could indicate that formalised industrial relations institutions have a declining role in UK call centres operations. Thus, further comparative research to examine country level institutional differences would further enlighten the debate on employee driven innovation activities.

If practitioners were to consider the findings of this research, they might look carefully at the management rhetoric around involvement schemes, whether focused on innovation or not. Almost all of the cases in this study had some top down management approaches, i.e. third order approach to employee involvement in innovation activities (Høyrup, 2012) but the job design and stringent performance targets hindered some employees' abilities to take part. This sets up a paradox of management saying one thing but not providing the mechanisms to effective involve their employees. Therefore, if managers want to open up their innovation process, as many now are, then they need to be aware of the impact the nature of work has on the way employees can be involved. They also 
need to consider their own role in the innovation process as the findings from this study has shown that there is potential for their jobs to intensify through the management of employees' ideas. Finally, it can be concluded that high involvement innovation has the potential to enrich frontline employees' jobs, making them feel more valued and giving them some variety and challenge in their job. Therefore practitioners should approach employee involvement in the innovation process as something potentially fruitful and not just wasted time away from the phones.

\section{References}

Aasen, T., Amundsen, O., Gressgård, L., \& Hansen, K. (2012). Employee-driven innovation in practice: promoting learning and collaborative innovation by tapping into diverse knowledge sources. Lifelong Learning in Europe, 4, 1-10.

Bain, P., \& Taylor, P. (2000). Entrapped by the 'electronic panopticon'? Worker resistance in the call centre. New Technology, Work and Employment, 15(1), 2-18.

Bain, P., \& Taylor, P. (2002). Ringing the changes? Union recognition and organisation in call centres in the UK finance sector. Industrial Relations Journal, 33(3), 246-261.

Bain, P., Watson, A., Mulvey, G., Taylor, P., \& Gall, G. (2002). Taylorism, targets and the pursuit of quantity and quality by call centre management. New Technology, Work and Employment, $17(3), 170-185$.

Batt, R. (2000). Strategic segmentation in front-line services: matching customers, employees and human resource systems. International Journal of Human Resource Management, 11(3), 540-561.

Bessant, J., \& Caffyn, S. (1997). High-involvement innovation through continuous improvement. International Journal of Technology Management, 14(1), 7-28.

Bessant, J. R., \& Bessant, J. (2003). High-involvement innovation: building and sustaining competitive advantage through continuous change: J. Wiley.

Bolton, S. C., \& Houlihan, M. (2005). The (mis) representation of customer service. Work, Employment \& Society, 19(4), 685-703.

Bolton, S. C., \& Laaser, K. (2013). Work, employment and society through the lens of moral economy. Work, Employment \& Society, 27(3), 508-525.

Boxall, P. (2003). HR strategy and competitive advantage in the service sector. Human Resource Management Journal, 13(3), 5-20.

Boxall, P., \& Macky, K. (2009). Research and theory on high-performance work systems: progressing the high-involvement stream. Human Resource Management Journal, 19(1), 3-23. doi:10.1111/j.1748-8583.2008.00082.x

Budd, J. W., Gollan, P. J., Wilkinson, A., Budd, J. W., Gollan, P. J., \& Wilkinson, A. (2010). New approaches to employee voice and participation in organizations. Human Relations, 63(3), 303-310.

Callaghan, G., \& Thompson, P. (2001). Edwards revisited: technical control and call centres. Economic and Industrial Democracy, 22(1), 13-37.

Chesbrough, H. (2003). The logic of open innovation: managing intellectual property. California Management Review, 45(3), 33-58.

Deery, S., Iverson, R., \& Walsh, J. (2002). Work relationships in telephone call centres: understanding emotional exhaustion and employee withdrawal. Journal of Management Studies, 39(4), 471-496.

Delbridge, R. (2007). HRM and contemporary manufacturing. Oxford Handbook of Human Resource Management, The, 405.

Doellgast, V. (2008). Collective Bargaining and High-Involvement Management in Comparative Perspective: Evidence from US and German Call Centers. Industrial relations: a journal of economy and society, 47(2), 284-319. 
Doellgast, V. (2010). Collective voice under decentralized bargaining: a comparative study of work reorganization in US and German call centres. British Journal of Industrial Relations, 48(2), 375-399.

Edwards, P., \& Wright, M. (2001). High-involvement work systems and performance outcomes: the strength of variable, contingent and context-bound relationships. International Journal of Human Resource Management, 12(4), 568-585.

Fuller, L., \& Smith, V. (1991). Consumers' reports: management by customers in a changing economy. Work, Employment \& Society, 5(1), 1-16.

Gioia, D. A., Corley, K. G., \& Hamilton, A. L. (2013). Seeking Qualitative Rigor in Inductive Research. Organizational Research Methods, 16(1), 15-31. doi:doi:10.1177/1094428112452151

Harley, B., Sargent, L., \& Allen, B. (2010). Employee responses to 'high performance work system'practices: an empirical test of the disciplined worker thesis. Work, Employment \& Society, 24(4), 740-760.

Howcroft, D., \& Wilson, M. (2003). Participation:'bounded freedom'or hidden constraints on user involvement. New Technology, Work and Employment, 18(1), 2-19.

Høyrup, S. (2010). Employee-driven innovation and workplace learning: basic concepts, approaches and themes. Transfer: European Review of Labour and Research, 16(2), 143-154. doi:doi:10.1177/1024258910364102

Høyrup, S. (2012). Employee-driven innovation: a new phenomenon, concept and mode of innovation Employee-Driven Innovation (pp. 3-33): Springer.

Høyrup, S., Bonnafous-Boucher, M., Hasse, C., Møller, K., \& Lotz, M. (2012). Employee-driven innovation: A new approach: Palgrave Macmillan.

Jenkins, S., Delbridge, R., \& Roberts, A. (2010). Emotional management in a mass customised call centre: examining skill and knowledgeability in interactive service work. Work, Employment \& Society, 24(3), 546-564.

Kinnie, N., Hutchinson, S., \& Purcell, J. (2000). 'Fun and surveillance': the paradox of high commitment management in call centres. International Journal of Human Resource Management, 11(5), 967-985.

Lawler III, E. E. (1986). High-Involvement Management. Participative Strategies for Improving Organizational Performance: ERIC.

Lloyd, C., \& Payne, J. (2009). 'Full of sound and fury, signifying nothing'interrogating new skill concepts in service work-the view from two UK call centres. Work, Employment \& Society, 23(4), 617-634.

Newman, M., \& Noble, F. (1990). User involvement as an interaction process: a case study. Information systems research, 1(1), 89-113.

Ramsay, H., Scholarios, D., \& Harley, B. (2000). Employees and high-performance work systems: Testing inside the black box. British Journal of Industrial Relations, 38(4), 501-531.

Russell, B. (2008). Call centres: A decade of research. International Journal of Management Reviews, 10(3), 195-219.

Taylor, P., \& Bain, P. (1999). 'An assembly line in the head': work and employee relations in the call centre. Industrial Relations Journal, 30(2), 101-117.

Taylor, P., \& Bain, P. (2003). 'Subterranean worksick blues': humour as subversion in two call centres. Organization Studies, 24(9), 1487-1509.

Thompson, P. (2013). Financialization and the workplace: extending and applying the disconnected capitalism thesis. Work, Employment \& Society, 27(3), 472-488.

Thompson, P., and, McHugh, D. . (2009). Work Organizations (4th ed.). Basingstoke: Palgrave Macmillan.

Tidd, J., \& Bessant, J. (2009). Managing innovation: integrating technological, market and organizational change. London Wiley 
Waite, E., Evans, K., \& Kersh, N. (2012). Employee-Driven Innovation Amongst 'Routine'Employees in the UK: The Role of Organizational 'Strategies' and Individual 'Tactics' Employee-Driven Innovation (pp. 149-164): Springer.

Wood, S., \& de Menezes, L. M. (2011). High involvement management, high-performance work systems and well-being. The International Journal of Human Resource Management, 22(7), 1586-1610. doi:10.1080/09585192.2011.561967

Wood, S., \& Ogbonnaya, C. (2016). High-Involvement Management, Economic Recession, WellBeing, and Organizational Performance. Journal of Management, O(0), 0149206316659111. doi:doi:10.1177/0149206316659111

Wood, S., Van Veldhoven, M., Croon, M., \& de Menezes, L. M. (2012). Enriched job design, high involvement management and organizational performance: The mediating roles of job satisfaction and well-being. Human Relations, 65(4), 419-445.

Yin, K. R. (2003). Case study Research: Design and methods. Sage publicatons. 